\title{
SOARING BIRD MIGRATION RESEARCH AT THE BOSPHORUS STRAIT, TURKEY
}

\author{
ARSLANGÜNDOĞDU, Z. ${ }^{1 *}-$ SMITH, L. $^{2}-$ YARDiM, $\ddot{U}^{2}{ }^{2}$ - VANMARCKE, P. J. ${ }^{2}-$ PAYNE, M. ${ }^{2 \dagger}$ \\ ${ }^{I}$ Department of Forest Entomology and Protection, Faculty of Forestry, Istanbul University \\ Cerrahpaşa, Istanbul, Turkey \\ ${ }^{2}$ Istanbul Bird Watching Society, Istanbul, Turkey \\ *Corresponding author \\ e-mail: zeynel@istanbul.edu.tr; phone: +90-212-338-2400/ext. 25256; fax: +90-212-338-2424 \\ (Received 14 ${ }^{\text {th }}$ Aug 2018; accepted $1^{\text {st }}$ Nov 2018)
}

\begin{abstract}
Soaring birds crossing the Bosphorus near Istanbul, Turkey, were monitored by the Istanbul Bird Watching Society (IBWS) in the 2007 spring season. During our research, we established an area that is significant for large numbers of migrating soaring birds crossing from Asia to Europe. In total the most abundant spp were White Storks (Ciconia ciconia) 44,566, Eurasian Buzzard (Buteo buteo) 23,954, Lesser Spotted Eagles (Clanga pomarina) 7,036 and European Honey Buzzards (Pernis apivorus) 3,653. We also compared our count to the count done in 1993, 2005 and 2006. This study in 2007 showed this site as crossing point for endangered Steppe Eagles (Aquila nipalensis) and Egyptian Vultures (Neophron percnopterus). This study included education outreach to visitors about the importance of Turkey for ornithology.
\end{abstract}

Keywords: Buteo buteo, Ciconia ciconia, Clanga pomarina, Pernis apivorus, Sariyer, Istanbul

\section{Introduction}

The Bosphorus Strait in Turkey has been known as an important soaring bird concentration point for hundreds of years. The first known report of the raptor migration bottleneck at the Bosphorus was in the spring of 1555 at an area known to local falconers (Belon, 1555). Unfortunately, since that time only a small number of attempts have been made to monitor spring soaring bird migration at this bottleneck. The most significant surveys of soaring birds at the Bosphorus are from the autumn in the years 1968-1975 conducted by the Ornithological Society of Turkey (Vittery and Squire, 1972; Kitson and Porter, 1970; Beaman, 1973, 1978; Beaman and Jacobsen, 1974; Beaman et al., 1975; Porter and Willis, 1968). Spring data is rare, limited in length and occurred at famous autumn observation sites which are poor locations for the spring season. Therefore, they are not useful for comparison, as discussed in Üner et al. (2010). The only serious study was conducted by members of Bird Life Hungary (MME) in 1993 (Bagyura et al., 2006) who conducted surveys at different sites and finally arrived the same area as Belon in 1555.

To obtain current figures of soaring birds at this site, spring monitoring projects were conducted by the Istanbul Bird Watching Society (IBWS). In the spring of 2005 , a preliminary survey was carried out to determine spring passage routes and dates and this led us to the area used by the falconers in 1555 and by MME in 1993 (Cirik and Smith, 2005; Simit and Yardim, 2006). Then during the spring migrations of 2006 (Üner et al., 2010) and 2007 a daily count was carried out through the season, assisted by the presence of veteran European bird watchers. 
There are few studies on the spring migration of soaring birds at the Bosphorus. This study aims to determine the species, density, migration route and migration dynamic of soaring birds over the Bosphorus Strait, as well as comparing results with the similar studies made in past years.

A secondary goal was on-site education. Our main observation site was located at a well-known scenic view site, so it received many visitors. We took the opportunity to educate visitors about the birds passing overhead and the importance of the area for migration.

\section{Materials and methods}

Our main site was approximately $1 \mathrm{~km} \mathrm{SW}$ of entry to Koç University on the edge of the road. The main point in observations made in 73 days in total is Keskin Viraj point where we observed for 65 days. The other observation points are Havantepe (5 days) and Anadolu Kavağı (3 days). Keskin Viraj is at $41^{\circ} 11^{\prime} 35^{\prime \prime} \mathrm{N}$, $29^{\circ} 04^{\prime} 28^{\prime} \mathrm{E}$ and is $198 \mathrm{~m}$ above sea level. Havantepe is at $41^{\circ} 10^{\prime} 34^{\prime} \mathrm{N}, 2^{\circ} 04^{\prime} 18^{\prime \prime} \mathrm{E}$ and is $112 \mathrm{~m}$ above sea level. Anadolu Kavağ 1 is at $41^{\circ} 10^{\prime} 43^{\prime \prime} \mathrm{N}, 2^{\circ} 05^{\prime} 43^{\prime \prime} \mathrm{E}$ and is $112 \mathrm{~m}$ above sea level (Fig. 1). Keskin Viraj observation point is chosen because experience has shown that in the soaring birds cross more towards the northern end the Bosphorus.

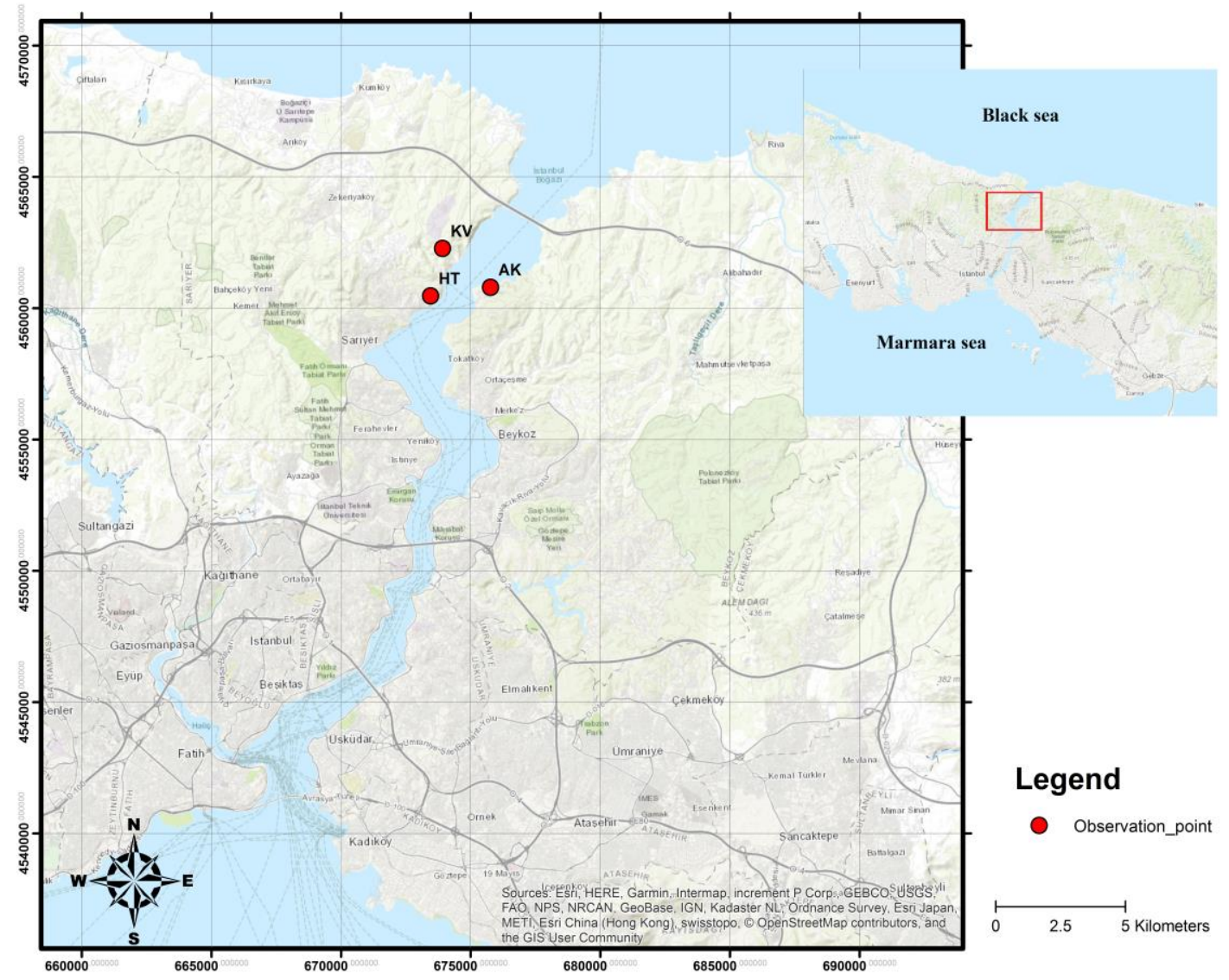

Figure 1. Observation points (Keskin Viraj (KV), Havantepe (HT), Anadolu Kavağ (AK)) 
Observations of migrating birds were recorded each day hourly and within each hour counts were recorded by flock sizes of each individual species. The potential directions that birds may pass over the observation site were regularly swept in vertical and horizontal plane with naked eye and telescope and binoculars, when necessary. After determining the species, individuals using the same altitude and direction were counted together. The passage of birds was observed on an individual basis during low-density migration and soring (not during thermal soaring) as indicated by Bildstein et al. (2007) and Sutherland (2006), while big groups were counted in groups of 5 and 10, and very dense groups in 20. Nikon Monarch $8 \times 42$ binoculars and Nikon Fieldscope 15-45 $\times 60$ telescopes were used for observation. The identification of difficult species was made from studies such as Forsman (1999) and Heinzel et al. (1995).

Daily observations for season took place between these dates: spring 2007 from 2/3$6 / 5,10 / 5-16 / 5,18 / 5,23 / 5,27 / 5,30 / 5,2 / 6-3 / 6$. Observations and counts were made between 2 March and 3 June (March/26 days, April/29 days, May/16 days, and June/2 days). Observations were performed between 9-17 $\mathrm{h}$ and the average was observed for $7 \mathrm{~h}$ a day.

Soaring bird species recorded at the Bosphorus Strait during spring migration in 2007, showing total observed numbers, the coefficient of variation average median date, date of first $5 \%$ and first $95 \%$ of passage and length of central $90 \%$ of passage (days). In the comparison of 2006 and 2007, the average of bird species' census results for these two years were taken.

The weather 02 March-03 June was very variable. On 24 of the 73 days of the period conditions were generally sunny, on 45 days it was fully or partially cloudy and on 4 days misty. Though lower on misty days, visibility was generally satisfactory. Rain occurred on 7 days. Prevailing winds were from the North-northeast (50 of 73 days) and South-southwest (13 of 73 days). When the wind direction changes from north to South the temperature can rise by $10{ }^{\circ} \mathrm{C}$. Meteorological data were provided by the Turkish State Meteorological Service (station code: 17061) (Fig. 2).

Meteorological data of years 1993, 2005, 2006 and 2007 were taken from Turkish State Meteorological Service, while for 1993 only average temperature data could be provided. Average temperatures were recorded as $6.3{ }^{\circ} \mathrm{C}(1993), 7.0{ }^{\circ} \mathrm{C}(2005), 8.6{ }^{\circ} \mathrm{C}$ (2006) and 8,7 ${ }^{\circ} \mathrm{C}$ (2007) in March; $10.6^{\circ} \mathrm{C}(1993), 11.9^{\circ} \mathrm{C}(2005), 11.1^{\circ} \mathrm{C}(2006)$ and $10.3{ }^{\circ} \mathrm{C}(2007)$ in April; $14.7{ }^{\circ} \mathrm{C}(1993), 15.3{ }^{\circ} \mathrm{C}(2005), 16.1{ }^{\circ} \mathrm{C}(2006)$ and $17.3{ }^{\circ} \mathrm{C}$ (2007) in May. Recorded total rainfall during the migration period of March, April and May was $112.8 \mathrm{~mm}$ (2005), $114.8 \mathrm{~mm}$ (2006) and $105.2 \mathrm{~mm}$ (2007), while prevail wind direction was NNE for the same period (Fig. 2).

\section{Results and discussion}

As a result of this research, three outputs were obtained. The most important output was detailed spring species accounts for migratory soaring birds for the whole season. Secondly, it was the determination the effects of weather on soaring birds. The last one was education outreach to participants, visitors and students.

\section{Species accounts}

The following data describes the species status for each year of spring migration over the Bosphorus, the amount of coverage during passage dates, each species first and last observed passage date and peak passage date. Count data from 2005 and 2006 were 
taken from our previous published surveys (Cirik and Smith, 2005; Üner et al., 2010). In 2007 we observed migration over the longest period of time.

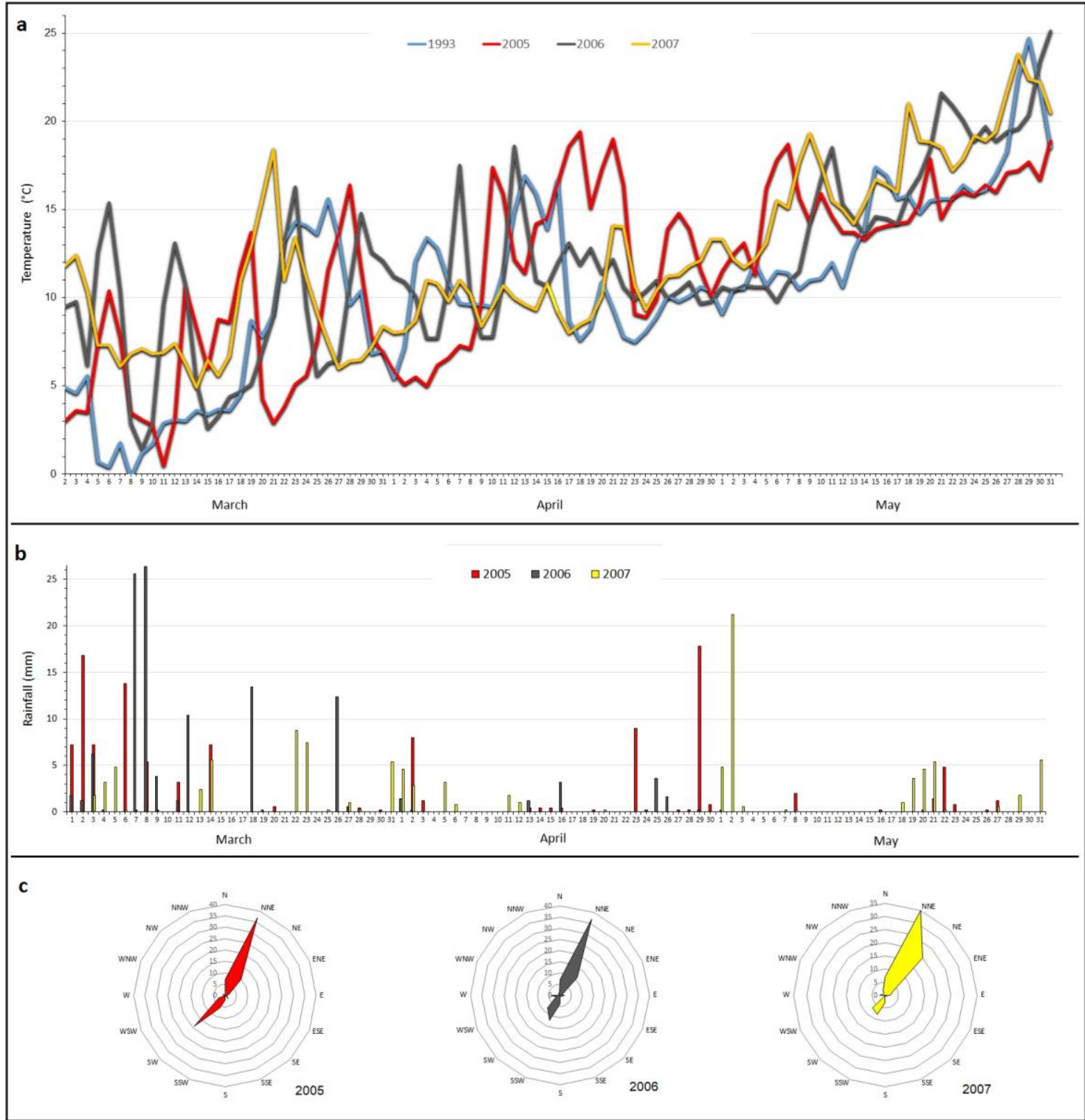

Figure 2. Meteorological data for the migration period a) Temperature b) Rainfall c) Prevail wind direction

Observations were made from 02 March - 03 June. A total of 83,560 soaring bids were counted, with White Stork, Eurasian Buzzard, Lesser Spotted Eagle and European Honey Buzzard being the most numerous species (Table 1). The birds in the table were first classified as orders Ciconiiformes, Accipitriformes and Falconiformes according to the systematic list. The species in each team were listed from most common to most rare. In Table 2 results for the years 1993, 2005, 2006 and 2007 were compared.

White stork Ciconia ciconia: White Storks are the most common species of soaring birds at the Bosphorus. In spring, similar to the Black Stork, White Storks were already passing at the beginning of the 2006 survey and were still passing at its finish: 
18/3/2006-31/5/2006 (Üner et al., 2010). In 2007, passage began on 08/3 and was still present on the study last day (03/6) (Fig. 3a). Peak spring passage days were 07/4/2006 (5,682) and 26/3/2007 (6,079). During the spring (Arslangündoğdu et al., 2011), opposite of the autumn passage (Arslangündoğdu et al., 2017), they move across the Bosphorus with an extremely broad passage where regular observation did not take place. Based on the observations from 2007, White Storks crossed the Bosphorus in large numbers in a variety of locations from the Sea of Marmara to the Black Sea.

Table 1. Number of migrant soaring birds counted crossing the Bosphorus at spring season observation points, Turkey, 02 March-03 June 2007

\begin{tabular}{|c|c|c|c|c|c|}
\hline Species & Total & $\begin{array}{c}\text { Median } \\
\text { date }\end{array}$ & $\begin{array}{l}\text { Date of } \\
\text { first } 5 \%\end{array}$ & $\begin{array}{c}\text { Date of } \\
\text { first } 95 \%\end{array}$ & $\begin{array}{c}\text { Length of } \\
\text { central } \\
90 \%\end{array}$ \\
\hline White Stork (Ciconia ciconia) & 44566 & 26 March & 19 March & 6 May & 48 \\
\hline Black Stork (Ciconia nigra) & 617 & 23 April & $20 \mathrm{March}$ & 13 May & 54 \\
\hline unid. Stork Ciconia & 64 & & & & \\
\hline Eurasian Buzzard (Buteo buteo) & 23954 & 26 March & 6 March & 28 April & 53 \\
\hline Lesser Spotted Eagle (Clanga pomarina) & 7036 & 6 April & 2 April & 6 May & 34 \\
\hline European Honey Buzzard (Pernis apivorus) & 3653 & 5 May & 1 May & 23 May & 22 \\
\hline Eurasian Sparrowhawk (Accipiter nisus) & 2219 & 7 April & 19 March & 3 May & 45 \\
\hline Short-toed Snake Eagle (Circaetus gallicus) & 249 & 7 April & $20 \mathrm{March}$ & 27 May & 68 \\
\hline Black Kite (Milvus migrans) & 126 & 9 April & $26 \mathrm{March}$ & 5 May & 40 \\
\hline Booted Eagle (Hieraaetus pennatus) & 116 & 7 April & 1 April & 3 May & 32 \\
\hline Western Marsh-harrier (Circus aeruginosus) & 75 & 8 April & $21 \mathrm{March}$ & 10 May & 50 \\
\hline Hen Harrier (Circus cyaneus) & 66 & 7 April & $18 \mathrm{March}$ & 30 May & 73 \\
\hline Long-legged Buzzard (Buteo rufinus) & 18 & 28 March & 19 March & 3 May & 45 \\
\hline Northern Goshawk (Accipiter gentilis) & 18 & 8 April & 7 March & 4 May & 58 \\
\hline Eastern Imperial Eagle (Aquila heliaca) & 15 & 29 April & 12 March & 23 May & 72 \\
\hline Montagu's Harrier (Circus pygargus) & 14 & 3 April & 19 March & 25 April & 37 \\
\hline Steppe Eagle (Aquila nipalensis) & 7 & & & & \\
\hline Osprey (Pandion haliaetus) & 5 & & & & \\
\hline Egyptian Vulture (Neophron percnopterus) & 4 & & & & \\
\hline Griffon Vulture (Gyps fulvus) & 4 & & & & \\
\hline Levant Sparrowhawk (Accipiter brevipes) & 3 & & & & \\
\hline Pallid Harrier (Circus macrourus) & 3 & & & & \\
\hline Golden Eagle (Aquila chrysaetos) & 2 & & & & \\
\hline White-tailed Sea-eagle (Haliaeetus albicilla) & 1 & & & & \\
\hline Cinereous Vulture (Aegypius monachus) & 1 & & & & \\
\hline Rough-legged Buzzard (Buteo lagopus) & 1 & & & & \\
\hline Greater Spotted Eagle (Clanga clanga) & 1 & & & & \\
\hline unid. Raptor Accipitridae & 272 & & & & \\
\hline unid. Buzzard Buteo / Pernis & 242 & & & & \\
\hline unid. Harrier Circus & 34 & & & & \\
\hline unid. Eagle Aquila & 26 & & & & \\
\hline unid. Sparrowhawk Accipiter & 11 & & & & \\
\hline Eurasian Hobby (Falco subbuteo) & 37 & 28 April & 19 March & 13 May & 55 \\
\hline Red-footed Falcon (Falco vespertinus) & 25 & 28 April & $21 \mathrm{March}$ & 6 May & 46 \\
\hline Common Kestrel (Falco tinnunculus) & 23 & 21 April & $18 \mathrm{March}$ & 12 May & 55 \\
\hline Peregrine Falcon (Falco peregrinus) & 14 & 2 April & 12 March & 28 April & 47 \\
\hline Merlin (Falco columbarius) & 2 & & & & \\
\hline unid. Falcon Falco & 36 & & & & \\
\hline Total & 83,560 & & & & \\
\hline
\end{tabular}

Black Stork Ciconia nigra: Common migrant. Black Storks were already passing at the beginning of the spring 2006 survey (18/3) and were still passing at its finish (31/5/2006) (Üner et al., 2010). In 2007, passage began on 12/3 and was still present on the study last day (03/6). Peak spring passage occurred on the same date in both years: 
25/3/2006 (207), 25/3/2007 (151) (Fig. 3b). Black storks crossed the Bosphorus on a broad front in the spring all across the Strait and therefore many were not counted due to incomplete coverage.

Table 2. Species totals by year and average totals between 2006 and 2007 in comparison to the most important study done in 1993 (Bagyura et al., 2006) and in 2005 (Cirik and Smith, 2005)

\begin{tabular}{|c|c|c|c|c|c|}
\hline Species & $\begin{array}{c}2005 \\
\text { Totals } \\
\end{array}$ & $\begin{array}{c}2006 \\
\text { Totals } \\
\end{array}$ & $\begin{array}{c}2007 \\
\text { Totals } \\
\end{array}$ & $\begin{array}{c}\text { '06-'07 } \\
\text { Avg. }\end{array}$ & $\begin{array}{c}1993 \\
\text { Totals } \\
\end{array}$ \\
\hline Observation days & 13 & 72 & 73 & & 27 \\
\hline Number of bird species & 23 & 32 & 31 & & 26 \\
\hline White Stork (Ciconia ciconia) & 5684 & 51958 & 44566 & 48262 & 80474 \\
\hline Black Stork (Ciconia nigra) & 52 & 1118 & 617 & 868 & 1616 \\
\hline unid. Stork Ciconia & & 51 & 64 & & \\
\hline Eurasian Buzzard (Buteo buteo) & 3125 & 16185 & 23954 & 20070 & 9078 \\
\hline Lesser Spotted Eagle (Clanga pomarina) & 3826 & 15232 & 7036 & 11134 & 20080 \\
\hline European Honey Buzzard (Pernis apivorus) & 349 & 9085 & 3653 & 6369 & $* 6$ \\
\hline Eurasian Sparrowhawk (Accipiter nisus) & 326 & 1701 & 2219 & 1960 & 1142 \\
\hline Short-toed Snake Eagle (Circaetus gallicus) & 66 & 473 & 249 & 361 & 271 \\
\hline Black Kite (Milvus migrans) & 30 & 223 & 126 & 175 & 101 \\
\hline Booted Eagle (Hieraaetus pennatus) & 90 & 161 & 116 & 139 & 80 \\
\hline Western Marsh Harrier (Circus aeruginosus) & 11 & 138 & 75 & 107 & *7 \\
\hline Hen Harrier (Circus cyaneus) & 3 & 92 & 66 & 79 & 28 \\
\hline Long-legged Buzzard (Buteo rufinus) & & 28 & 18 & 23 & \\
\hline Northern Goshawk (Accipiter gentilis) & & 5 & 18 & 12 & 30 \\
\hline Eastern Imperial Eagle (Aquila heliaca) & 1 & 32 & 15 & 24 & \\
\hline Montagu's Harrier (Circus pygargus) & & 12 & 14 & 13 & $* 2$ \\
\hline Steppe Eagle (Aquila nipalensis) & 3 & 5 & 7 & 6 & 4 \\
\hline Osprey (Pandion haliaetus) & 4 & 9 & 5 & 7 & 3 \\
\hline Egyptian Vulture (Neophron percnopterus) & 3 & 11 & 4 & 8 & 17 \\
\hline Griffon Vulture (Gyps fulvus) & & 9 & 4 & 7 & 7 \\
\hline Levant Sparrowhawk (Accipiter brevipes) & 76 & 16 & 3 & 10 & \\
\hline Pallid Harrier (Circus macrourus) & 1 & 10 & 3 & 7 & $* 1$ \\
\hline Golden Eagle (Aquila chrysaetos) & & 1 & 2 & 2 & \\
\hline White-tailed Sea Eagle (Haliaetus albicilla) & 1 & 2 & 1 & 2 & \\
\hline Cinereous Vulture (Aegypius monachus) & & 1 & 1 & 1 & \\
\hline Rough-legged Buzzard (Buteo lagopus) & & 2 & 1 & 2 & \\
\hline Greater Spotted Eagle (Clanga clanga) & 7 & 9 & 1 & 5 & 1 \\
\hline Bonelli's Eagle (Aquila fasciata) & & 1 & & & 2 \\
\hline Red Kite (Milvus milvus) & & & & & 4 \\
\hline unid. Raptor Accipitridae & & 112 & 272 & & 1196 \\
\hline unid. Buzzard Buteo / Pernis & & 3082 & 242 & & 44 \\
\hline unid. Harrier Circus & & 7 & 34 & & 8 \\
\hline unid. Eagle Aquila & 2 & 25 & 26 & & 2 \\
\hline unid. Sparrowhawk Accipiter & & 12 & 11 & & 32 \\
\hline Eurasian Hobby (Falco subbuteo) & 9 & 64 & 37 & 51 & $* 2$ \\
\hline Red-footed Falcon (Falco vespertinus) & & 50 & 25 & 38 & \\
\hline Common Kestrel (Falco tinnunculus) & 9 & 55 & 23 & 39 & 26 \\
\hline Peregrine Falcon (Falco peregrinus) & 9 & 1 & 14 & 8 & 1 \\
\hline Merlin (Falco columbarius) & 1 & & 2 & 1 & 1 \\
\hline Saker Falcon (Falco cherrug) & & 1 & & & \\
\hline Lesser Kestrel (Falco naumanni) & & & & & 1 \\
\hline unid. Falcon Falco & 12 & 10 & 36 & & 3 \\
\hline Total & 7964 & 99,989 & 83,560 & & \\
\hline
\end{tabular}

*This count is not representative because observations did not occur during significant portions of this species passage dates or passage location 
Eurasian Buzzard Buteo buteo: These species represent nearly fifty percent of each year's raptor total. In the spring, they are the first raptor to migrate with small numbers being observed in late February. Spring migration occurred in two waves (Fig. 4). After the peaks, migration was seen by the authors in small numbers until the first week of July. Our preliminary survey in 2005 revealed the presence of large numbers as early as 12 March (816). In 2006, daily counts did not start until 18 March and Buzzard numbers were already significant and climbing each day with a notable peak on 26/3/2006 $(1,840)$, with the 2nd peak between 11/4/2006-13/4/2006 (2,144) (Üner et al., 2010). In 2007, counts began on 02 March after numbers of Buzzards were first beginning to aggregate in farm fields west of the Bosphorus.

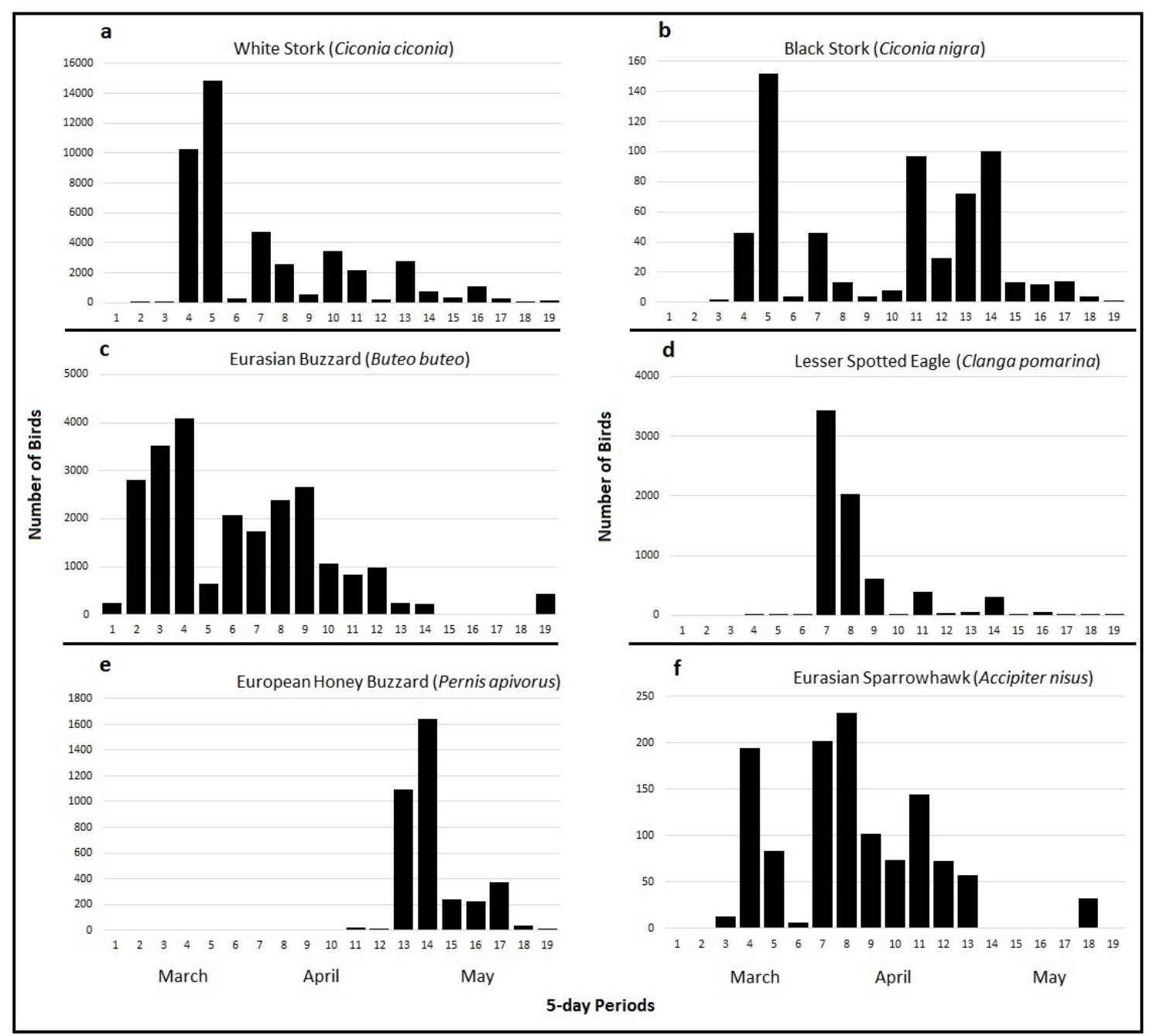

Figure 3. Spring 2007 count numbers 02 March- 03 June shown as 19 periods of 5 days. Graphs are for the first six species ( $a$-White Stork, b-Black Stork, $c$-Eurasian Buzzard, $d$-Lesser Spotted Eagle, e-European Honey Buzzard, f-Eurasian Sparrowhawk) listed in Table 1

The first two weeks of migration occurred over Havantepe where we started observations. Then it shifted further north to our normal site SE of Koc University. The peak day occurred during the first wave on 12/3/2007 $(2,075)$ and the second wave was most notable between 06/4/2007-10/4/2007 (4,101). A week-long observation done in 
2002 (MME, 2007) showed a notable peak on $15 / 4(2,143)$. The first peak was in the third period (12-16 March) of five day periods in 2007, while 2nd peak was determined in the 9th period (07-11 April) (Fig. 3c).

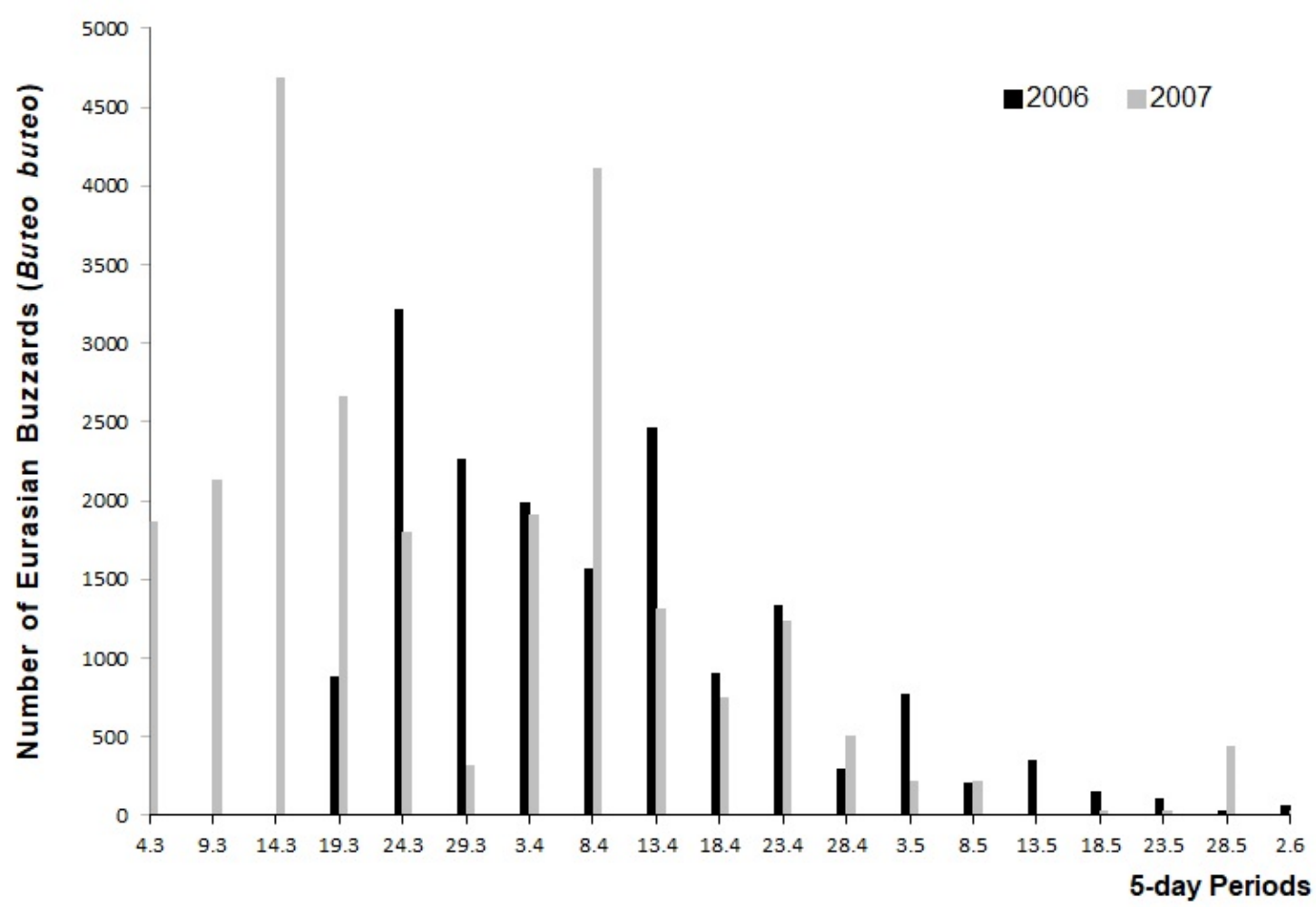

Figure 4. Pentad totals of the mid-90\% of Buteo buteo counted at the Bosphorus, Turkey in spring 2006 and 2007. From the graphic the larger number of Buzzards counted in $2007 \mathrm{vs}$ 2006 can be explained by the fact that counts did not start until 18 March in 2006

Lesser Spotted Eagle Clanga pomarina: This species is the second most common raptor and can be seen in large numbers during peak passage in both seasons. Spring passage was observed during the entire 2005 and 2006 projects 18/3/2006-31/5/2006 and started on 19/3/2007 and a few were still passing on the project's last day (03/6/2007). Peak passage dates were 10/4/2005 (1,566) (Cirik and Smith, 2005), $31 / 3 / 2006(3,673)$ and 04/4/2007 (2,553); approximately the first week of April in 2006 (Üner et al., 2010), 51\% of passage occurred, and 77\% in 2007 (Fig. 3d). Totals from spring 2007 are less than half of the average seasonal total from the previous three seasons. This was because the weather shifts that year caused them to migrate significantly further south out of the observers' view. This species crosses at very low altitudes in the spring and presents much difficulty viewing them in the central area of the strait.

European Honey Buzzard Pernis apivorus: This species is a common migrant throughout the area. Complete season counts were not conducted for European Honey Buzzards because of lack of personnel and funding due to this species migration patterns. In the spring, they are the latest migratory raptor with the initial starting dates of 12/4/2006 (Üner et al., 2010) and 21/4/2007. The peak spring dates were 12/5/2006 $(1,185)$ and $3 / 5 / 2007(921)$. In all three years we were not able to continue counts to 
determine their finish dates, but numbers significantly dropped during the first week of June (Fig. 3e). In the spring of 2007, many days that were believed to be significant for this species were missed due to observers' health and therefore reflect the low number. Passage appears to be more concentrated in the spring than the autumn (Arslangündoğdu, 2011). Unlike all other raptors, they complete their passage in the second half of migration season in May (Fig. 3e). In 2006, 90\% of the migration was completed between May 02 and May 29 (Üner et al., 2010) and between May 01 and May 23 in 2007.

Eurasian Sparrow Hawk Accipiter nisus: Relatively common in both seasons. Autumn migration occurs over a broad front across the Bosphorus Strait. Autumn concentrations of sparrow hawks were observed by the authors at a site further west of the strait where no regular observation takes place. In the Spring as many as three times more Sparrow Hawks were counted than historic autumn highs when they pass over a broad front (Gensbol, 1995, Bossche and Lens, 1994), yielding the highest totals ever published at the Bosphorus. These high count numbers are due to heavy concentrations and low altitudes used by the birds. Spring passage took place from 20/3/200622/5/2006 (Üner et al., 2010) and 15/3/2007-30/5/2007 (Fig. 3f). Peak spring passage occurred on 02/4/2006 (125) and again on 02/4/2007 (93). These high spring numbers are comparable to anecdotal autumn counts compiled by one of the authors from local falconers.

Short-toed snake eagle Circaetus gallicus: Common species during migration in moderate numbers. Autumn counts show much higher numbers of Short-toed Snake Eagles than spring counts (Arslangündoğdu, 2011). It is unclear if low spring numbers could be due to a broader front migration during that time or from large winter mortality. As in autumn, spring season passage dates were broad and small numbers were still present during the last days of each count. Known passage occurred throughout the spring in 2005 and from 20/3/2006-31/5/2006 and 12/3/07-03/6/2007 (Fig. 5a). This species was a steady migrant throughout the season as can been seen from irregular peak passage dates: 20/4/2005 (23) (Cirik and Smith, 2005), 26/3/2006 (43) (Üner et al., 2010), 20/3/2007 (20), 03/4/2007 (20). The low spring 2007 total is most likely due to missed count days after the first week of May when significant passage still occurs. Irregular observations in 2001 (Kusbank, 2008) recorded high days on 21/3 (25) and 29/3 (20) supporting the last week of March as a key period. There is a notable peak in the 7th period (2-6 April) of five days periods in 2007 (Fig. 5a).

Black Kite Milvus migrans: Black Kites were the first species mentioned in historical raptor migration literature at our main observation site in the spring of 1555 when they were described to be as numerous as ants (Belon, 1555). Since that time they have experienced serious declines as breeders and as migrants throughout Turkey. Autumn counts show much lower numbers due to the broader and more southerly migration path; whereas they appear to be very concentrated in the spring. Peak passage in the spring occurred in two waves for all three years during mid-April and then again in mid-May with the greatest single day being 07/5/2006 (21) (Üner et al., 2010). Initial passage dates were 21/3/2006, 07/3/2007. As with the other late migrants, complete spring counts during the Black Kites passage have not occurred, but it is unlikely that much passage occurs after the third week of May (Fig. 5b).

Booted Eagle Hieraaetus pennatus: Uncommon in both seasons. Spring passage was observed from 22/3/2006-31/5/2006 (last day of project) (Üner et al., 2010) and 16/3/2007-03/6/2007 (last day of study). Peak spring dates were 06/4/2006 (25) and 18 
passed on both 02/4/2007 and 07/4/2007 (Fig. 5c). By assuming that missed days in May of 2007 had similar passage to 2006, then the total passage would be very near the previous spring counts. Over $50 \%$ of the total passage occurred in the first half of April each year. The highest passage day was recorded during a one week study in 2002 14/4 (31) (MME, 2007).

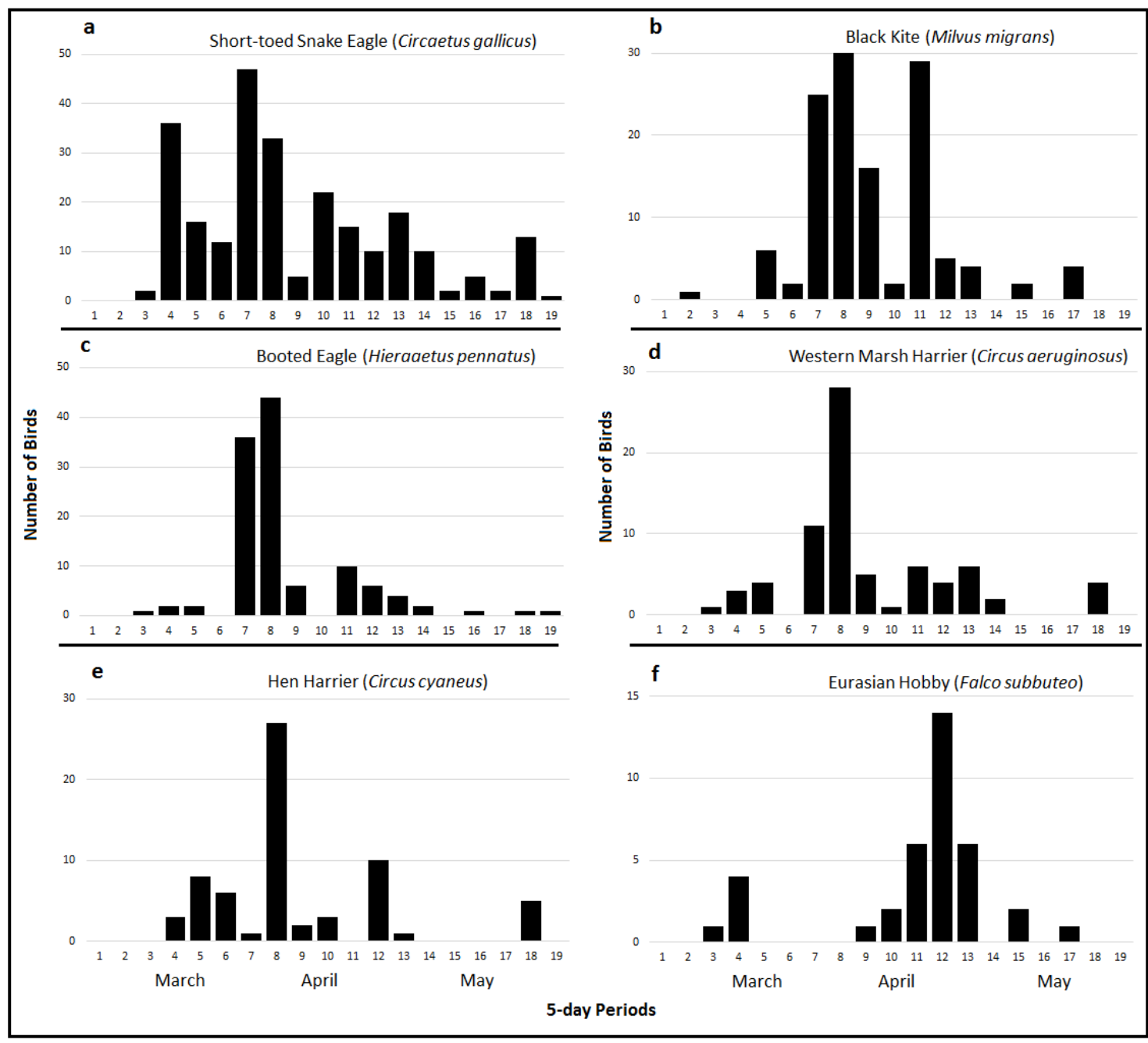

Figure 5. Spring 2007 count numbers 02 March- 03 June shown as 19 periods of 5 days. Graphs are for the 7th-12th species (a-Short-toed Snake Eagle, b-Black Kite, c-Booted Eagle, $d$-Western Marsh Harrier, e-Hen Harrier, f-Eurasian Hobby) listed in Table 1

Western Marsh Harrier Circus aeruginosus: Spring counts from 2005-2007 revealed much higher migrant numbers than was historically known from multi-station autumn counts. Therefore, Marsh Harriers might cross into Asia at another location in the autumn. Spring passage start dates were 12/3/2005 (Cirik and Smith, 2005), 18/3/2006 (start of study) (Üner et al., 2010) and 16/3/2007 (Fig. 5d). Marsh Harriers were still noted on the last day of counts for each year. Peak spring passage occurred on 22/4/2006 (14) and 07/4/2007 (15).

Hen Harrier Circus cyaneus: Autumn versus spring counts of Hen Harriers reveal the same pattern discussed with the Marsh Harrier. Spring passage was from 23/3/2006- 
28/4/2006 (Üner et al., 2010) and 18/3/07-30/5/2007 (Fig. 5e). Peak dates in spring were 10/4/2006 (10), 07/4/2007 (10) and 28/4/2007 (10).

Eurasian hobby Falco subbuteo: Uncommon. Locally nesting birds could have confused counts but it is presumed local birds were recognized and not counted. Spring passage was observed from 03/4/2006-31/5/2006 (last day of study) (Üner et al., 2010) and 15/3/2007-23/5/2007 (Fig. 5f). In the spring, the peak days were 06/5/2006 (6) and 28/4/2007 (11).

Red-Footed Falcon Falco vespertinus: Uncommon. Spring passage occurred from 03/5/2006-23/5/2006 (Üner et al., 2010) and 21/3/2007-12/5/2007. Peak spring passage days were 06/5/2006 (14) and 28/4/2007 (9). In approximately the first week of May in $2006,84 \%$ of total passage took place and $64 \%$ in 2007 . Larger numbers in the spring vs. autumn counts are most likely due to more concentrated passage.

Common Kestrel Falco tinnunculus: Small numbers of migrants recorded every season. Spring passage was observed from 22/3/2006-31/5/2006 (last day of count) (Üner et al., 2010) and 18/3/2007-30/5/2007. Peak spring passage days were 02/4/2006 (4), 11/4/2006 (4) and 28/4/2007 (3).

Long-Legged Buzzard Buteo rufinus: Uncommon during both seasons but possibly occurs in slightly higher numbers due to confusion during passage within large groups of Steppe Buzzards. Spring passage was noted between 20/3/2006-31/5/2006 (Üner et al., 2010) and from 19/3/2007-03/5/2007. Peak spring passage occurred on 09/4/2006 (12) and no significant peak was observed in 2007.

Northern Goshawk Accipiter gentilis: Rare broad-front migrant in both seasons. Possibly misidentified as a sparrow hawk on some occasions. Spring passage dates were observed from 20/3/2006-24/5/2006 (Üner et al., 2010) and 07/3/2007-30/5/2007 with no discernible peak.

Eastern Imperial Eagle Aquila heliaca: Observed in small numbers every season. Spring passage was observed between 21/3/2006-24/5/2006 (Üner et al., 2010) and $12 / 3 / 2007-03 / 6 / 2007$. Individuals earlier in the season were in pre-adult plumage with individuals recorded later identified as adults.

Montagu's Harrier Circus pygargus: An uncommon migrant. This species was observed in slightly higher numbers in the spring vs. fall. Spring totals are comparable with historic multi-station autumn counts (Beaman, 1973, 1978). Spring passage dates were between 31/3/2006-16/5/2006 and 19/3/2007-25/4/2007. Peak spring numbers occurred on 22/4/2006 (5) and 03/4/2007 (3). A one week study in 2002 (MME, 2007) recorded 4 on each day on both 14/4 and 15/4.

Peregrine Falcon Falco peregrinus: This species is fairly rare in the area and peregrines are actively taken for illegal sale in both seasons. In spring of 2006, the only confirmed observation occurred on 30/4 (Üner et al., 2010) and in 2007 passage was observed from 12/3/2007-29/4/2007.

Steppe Eagle Aquila nipalensis: Very rare migrant only recorded in spring. In spring of 2005, there was one confirmed sighting and an additional two unconfirmed (Cirik and Smith, 2005). In spring of 2006 (Üner et al., 2010), five unconfirmed sightings occurred. In spring of 2007, six were confirmed and one most likely, but unconfirmed record. A single adult was recorded on 19/3/2007 with the rest being juveniles which passed between 28/4-03/5. The lack of autumn records could be due to confusion for both species of Spotted Eagles because of the high altitudes at which most birds pass. Therefore, the much lower altitude observed in the spring allows distinctive 
features to be sighted and photographed making this an important site for this endangered species.

Osprey Pandion haliaetus: Observed in small numbers every season. Spring passage was observed between 01/4/2006-22/4/2006 (Üner et al., 2010) and 27/3/2007$23 / 5 / 2007$. Spring count numbers are hard to confirm because of the habit of ospreys to stay in the area for several weeks before passing further on. A few individuals were thought to be identified by some distinguishing features and therefore not counted twice, but in truth, numbers are unconfirmed.

Egyptian Vulture Neophron percnopterus: This species has experienced severe declines in the area as a breeder and is now a rare migrant (Boyla and Arslan, 2008). Spring passage occurred from 23/3/2006-23/5/2006 (Ǘner et al., 2010) and 20/3/0713/5/2007. Peak dates were 27/3/2005 (2), 23/3/2006 (2), 10/5/2006 (2).

Griffon Vulture Gyps fulvus: Large declines are apparent over the last 30 years of various records across Turkey as the species is now rare as a migrant and resident. In 2006, spring passage took place from 27/3/2006-23/5/2006 with the peak date of 28/3/2006 (2) (Üner et al., 2010). In the spring of 2007 the first was seen on 03/4/2007 and the last passage is not known due to missed count days in late May.

Levant Sparrow Hawk Accipiter brevipes: Only observed in significant numbers in autumn and can be seen in large flocks. Interestingly enough one of the regional names for this species is the Summer Sparrow Hawk. The bulk of their spring passage was found to occur across the Western Marmara Sea (Tuncali, 2010).

Pallid Harrier Circus macrourus: Occurs in low numbers. In the spring of 2005 the only observation was on 02/4 (1) (Cirik and Smith, 2005). In 2006, passage occurred from 26/3/2006-19/4/2006 with the peak date being 26/3/2006 (3) (Üner et al., 2010). In spring of 2007 sightings occurred on 15/4/2007 (1) and 29/4/2007 (2).

Golden Eagle Aquila chrysaetos: Observed in spring only on 21/5/2006 (1) (Üner et al., 2010) and 20/3/2007 (2).

Merlin Falco columbarius: Observed in spring only on 06/4/2007 (1) and 09/4/2007 (1).

White-Tailed Eagle Haliaeetus albicilla: A scarce migrant. Sightings occurred on 13/3/2005, 4/9/2005 (Cirik and Smith, 2005), 16/4/2006, 22/5/2006 (Üner et al., 2010), 29/3/2007.

Cinereous Vulture Aegypius monachus: Historically occurred in low numbers but now is very rare in the area. In the spring of 2006 and 2007 one has been seen during the first week of April (07/4/2006, 03/4/2007) (Üner et al., 2010).

Rough-Legged Buzzard Buteo lagopus: The only sighting occurred on 15/4/2006 (2) (Üner et al., 2010) passing within one hour and 04/4/2007 (1). A one week count done in 2002 (MME, 2007) recorded one at the similiar date of 18/4.

Greater Spotted Eagle Aquila clanga: Rare in both seasons and due to identification difficulties very few confirmed records are from the autumn and spring. Observed in spring only on 07/4/2007 (1).

The species observed in other years except 2007 are Red Kite (Milvus milvus), Bonelli's Eagle (Aquila fasciata), Saker Falcon (Falco cherrug) and Lesser Kestrel (Falco naumanni) (Table 2).

\section{Effects of weather}

As in the Balkans the main wind direction is from the North, with about $15 \%$ of winds from the South (Arslangündoğdu et al., 2011). In the spring, all raptor species 
have been found to be much more concentrated in one area between Sariyer and the Black Sea with winds shifting them a short distance north or south. Wind from the north tended to blow all species of birds a little further south. Wind from the south tended to blow all species of birds' further north. Strong thermals resulting from increased air temperatures caused the birds to fly higher than average making counts more difficult.

Instant weather conditions by the observation point directly affect birds. The soaring routes of the birds over the Bosphorus were mainly from northeast to southwest and from east to west, at the observation point. In general, birds passed at a lower altitude in the morning and a higher altitude in the afternoon.

Wind from the north tended to blow the birds to the south of observation point. Wind force and air temperature determines how south the birds were blown. This is particularly obvious after 11.00. However nearly half of the birds passed from north of observation point even during the northern wind. This is mainly because of the low thermals causing birds to fly lower than average and being less affected by the blowing force of wind. A similar observation was the bird's preference of the northern part in all weather conditions from March to early April. Southern wind tended to blow the birds above and north of the observation point. Birds headed towards the mouth of Black Sea or passed over the observation point due to the wind force and air temperature.

Relative low temperatures in early morning hours forced birds to fly at a lower altitude rarely flapping their wings, while the temperatures and thermal raising through the midday forced them to fly at higher altitudes. Ascending birds were more affected by the wind and forced to move due to the thermal and direction of wind. In very hot days it got hard to observe birds with naked eye except for the morning hours. Liechti et al. (1996) have observed that storks generally fly at a lower altitude in the morning and at a higher altitude when thermal currents are at their greatest. Our observations confirmed these records.

During the rainfall, there was a minimum or no bird passage at all. Scattered rain clouds through bird's passage direction may totally stop their flight. This break resulted with their gathering in a particular region. Then migration started following suitable weather conditions. On the contrary, collective and intense passages are observed in conditions which rain clouds come after birds. No passages were recorded within rainy days, while intense and collective passages were observed before and after rainfall during the observations held in 2006 and 2007.

\section{Educational}

At the main sites in 2007 we talked to 576 visitors about migrating birds and the importance of Turkey for ornithology. Doğa Derneği (The Nature Association) hosted a Migration Day event with the authors. A national photo club (Trakus) joined the migration count for a day, in conjunction with their annual meeting. Educational presentations were also given at local schools. Within the IBWS itself, many members were able to learn about conducting wildlife research and bird identification. The site was also visited by bird watcher from across the country and from 17 different countries. There were opportunities for mass media public education including five television features (twice on national and three times on Istanbul channels) along with articles in local newspapers and one Dutch newspaper. 


\section{Conclusion}

The results reported in this paper from 2005-2007 document the annual significance of the Bosphorus Strait as an important bottleneck for soaring bird spring migration. As a result of this study, totally 83,560 individuals of 31 species were observed in 2007 . Although this number significantly represents the real number of birds passed over Bosphorus during spring migration, it does not reflect the while amount. The most common soaring birds were White Stork $(44,566)$, Eurasian Buzzard $(23,954)$, Lesser Spotted Eagle $(7,036)$ and European Honey Buzzard $(3,653)$, respectively. As the observations would be conducted from more observation points from north to south covering whole Bosphorus, obtained number of birds would be closer to the real number of passing birds.

Instant weather conditions by the observation point directly affect the passage of the birds. No passage was recorded during rainy days. Cumulative and intense passages were observed before and after the rainfall in 2006 and 2007. It was observed that birds were soaring at a lower altitude in morning hours, while with the rise of air temperature and strong thermals they soar at higher altitudes.

Prevail wind direction at observation points was NNE in years 2005, 2006 and 2007. Northern winds tended to blow birds to the south of observation point, while southern winds tended to blow them to the north.

A complete count during the passage timeframe for many species was accomplished. Similar data from different years and season counts would suggest that accurate numbers for certain species were counted. Most species numbers appear to be stable during the years of this survey. The exception is the low numbers of Lesser Spotted Eagles recorded in the spring of 2007. Count numbers were only half of the three previous seasonal totals. It is most likely because of the weather conditions allowed large numbers of birds to migrate in a short time frame in an area undetected by observers. Several hundred were observed by one author too far south to see from our normal locations. This was near the second bridge and this same phenomenon was noted by the authors' random sightings in later years.

Spring counts at this site can be argued to be more important than autumn ones for European breeding population data. This is because they yield important numbers of birds that have survived a significant portion of their migration and therefore will most likely enter into the breeding population. Table 2 shows the totals of each species per season from spring 2005 to spring 2007. From this table it can been seen that the three most abundant species were: (1) White Stork (Ciconia ciconia), (2) Eurasian Buzzard (Buteo buteo) and (3). Lesser Spotted Eagle (Clanga pomarina). Migration monitoring at this site has regularly recorded the presence of five species of concern as listed by the Global Raptor Information Network (GRIN) (2012) and IUCN (2016): Egyptian Vulture (Neophron percnopterus), Pallid Harrier (Circus macrourus), Greater Spotted Eagle (Clanga clanga), Eastern Imperial Eagle (Aquila heliaca) and Red-Footed Falcon (Falco vespertinus). Most importantly was confirmation of this site in 2007 as a crossing point for of the endangered Steppe Eagles and Egyptian Vultures (Neophron percnopterus) heading to Europe. Soaring bird migration monitoring at this site is important for recording population dynamics for many species.

Some significant differences can be noted between the averages of springs 20062007 compared to the only lengthy historical count conducted in 1993 (Bagyura et al., 2006). The Black Stork (Ciconia nigra) counts appear down from 1,616 to 868 but this could be due to weather as stork spp. were found to follow an irregular route in spring 
season. Eurasian Buzzard (Buteo buteo) counts are significantly up at 20,070 from 9,078 as the count location and dates are similar. Autumn counts also show higher numbers from historical counts. In the same fashion the Eurasian Sparrow Hawk (Accipiter nisus) numbers are up from 1,142 to 1,960. This trend is also confirmed by anecdotal data from local Sparrow Hawk falconers. One species of concern, the Egyptian Vulture's (Neophron percnopterus) data shows a significant decline given the limited numbers of days observed in 1993 vs the much longer surveys of 2006 and 2007. Though these numbers are low to begin with, the decline from 17 in half the time to an average of only 7 with double the count days is consistent with the decline seen in our recent unpublished autumn counts vs historical counts. Lesser Spotted Eagle (Clanga pomarina) numbers show a notable decline of nearly $25 \%$ since 1993 from 20,080 to 15,232 by omitting the extra low 2007 data. This decline is further supported by our highest autumn survey in $2006 \mathrm{n}=16,185$; which includes young birds that have winter mortality before returning on the spring migration.

The data from these spring counts has contributed much information about soaring bird movements between Europe and Turkey that was previously unknown. The migration monitoring effort's biggest success was the education of Turkish nationals about the importance of bird life in Turkey. Local bird watchers were recruited to help with migration counts, their bird identification skills were developed and they went on to conduct monitoring in subsequent years at this site and others. It is the authors' hope that this data will be used to promote conservation in Turkey. Additionally, we hope it will encourage further funding for monitoring in both seasons along with the participation of local and foreign bird watchers.

Acknowledgements. This project was made possible by long hours spent in the field by many members of the IBWS. Special thanks are due to Ertugrul Birel who volunteered for two seasons consecutively. Permission to access areas for the spring migration was granted by the Turkish Military and the Sariyer Head District Official. We are very grateful to the European Union Youth Commission, Ozkan Uner and OSME for a big help in funding this project at different times. Gaye Mangum from the US Bureau of Land Management and English teacher Liz Smith were key in editing the manuscript. We dedicate this work to the memory of Margaret Payne, who was eliminated from our accident end result.

\section{REFERENCES}

[1] Arslangündoğdu, Z. (2011): Autumn-2007 migration of soaring birds across the Bosphorus Turkey. - Journal of the Faculty of Forestry Istanbul University 61(2): 39-44.

[2] Arslangündoğdu, Z., Dalyan, C., Bacak, E., Yardim, U., Gezgin, C., Beskardes, V. (2011): Spring migration of the White Stork, Ciconia ciconia, and the Black Stork, Ciconia nigra, over the Bosphorus. - Zoology in the Middle East 53(1): 7-13.

[3] Arslangündoğdu, Z., Bacak, E., Beskardes, V., Dalyan, C., Smith, L., Payne, M. R., Yardım, Ü. (2017): Autumn migration of the White Stork, Ciconia ciconia, and the Black Stork, C. nigra, over the Bosphorus (Aves: Ciconiidae). - Zoology in the Middle East 63(2): 1-6.

[4] Bagyura, J., Günes, B., Filotás, Z., Harangi, I., Haraszthy, L., Kalocsa, B., Boyla, K., Klinker, J., Tevely, R., Tamás, E. A., Viszló, L. (2006): Bírd census during spring migration at the Bosphorus - 1993. - Heliaca 2006: $74-79$ (in Hungarian).

[5] Beaman, M. (1973): Bosphorus migration, autumn 1971. - Bulletin of the Ornithological Society of Turkey 8: 3-4. 
[6] Beaman, M. (1978): Bird Report No. 4 (1974-1975). - Ornithological Society of Turkey, Sandy (Bedfordshire).

[7] Beaman, M. Jacobsen, F. (1974): Bosphorus migration, autumn 1972. - Bulletin of the Ornithological Society of Turkey 10: 10-11.

[8] Beaman, M., Porter, R. F., Vittery, A. (1975): Bird Report No. 3 (1970-1973). Ornithological Society of Turkey, Sandy, Bedfordshire.

[9] Belon, P. (1555): L'Histoire de la nature des Oyseaux, avec leurs descriptions et naif $\backslash$ portraicts, rerirez du naturel escrite en sept livres. - G. Corrozet edit., Paris.

[10] Bildstein, K. L., Smith, J. P., Yosef, R. (2007): Migration Counts and Monitoring. - In: Bird, D. M., Bildstein, K. L. (eds.) Raptor Research and Management Techniques. Hancock House, Surrey, UK.

[11] Bossche, W. van den, Lens, L. (1994): Soaring bird migration at the Bosphorus (Turkey): the need for a multi-station survey. - Le Gerfaut 84: 51-62.

[12] Boyla, K., Arslan, M. (2008): İstanbul'un Kuşları: 2008. - İstanbul Kuş Gözlem Topluluğu, İstanbul (in Turkish).

[13] Cirik, Ö, Smith, L. (2005): Spring Raptor Migration at the Bosphorus, Turkey. - 37th CIESM Congress Proceeding, Barcelona-Malaysia, pp. 1-7.

[14] Forsman, D. (1999): The Raptors of Europe and the Middle East: A Handbook of Field Identification. - T. \& A. D. Poyser, London.

[15] Génsbøl, B. (1995): Rovfuglene i Europe, Nordafrika og Mellemøsten. - GAD, Kobenhavn (in Danish).

[16] Heinzel, H., Fitter, R., Parslow, J. (2001): Türkiye ve Avrupa'nın Kuşları (Kuzey Afrika ve Ortadoğu dahil) (Çeviren: Kerim Ali Boyla). - Doğal Hayatı Koruma Derneği, İstanbul (in Turkish).

[17] Kitson, A. R., Porter, R. F. (1970): News from the Bosphorus autumn 1969. Ornithogical Society of Turkey Bulletin 5: 4.

[18] KusBank (2008): Turkish Bird Database (Istanbul Bogaz, 18-29.03.2001). www.worldbirds.org/v3/turkey.php (visited: 24.01.2008).

[19] Liechti, F., Ehrich, D., Bruderer, B. (1996): Flight Behaviour of White Storks Ciconia ciconia on their migration over southern Israel. - Ardea 84: 3-13.

[20] MME (2007): The Hungarian Ornithological and Nature Conservation Society (Ornithological Society of Hungary Migration Count at Anadolu Kavagi in 2002). Unpublished project report.

[21] Porter, R. F., Willis, I. R. (1968): The Autumn migration of soaring birds at the Bosporus. - Ibis 110: 520-536.

[22] Simit, L., Yardim, Ü. (2006): Monitoring bird migration at the Bosphorus. - Heliaca 2006: 73 (in Hungarian).

[23] Sutherland, W. J. (2006): Ecological Census Teqniques. - Cambridge University Press, New York.

[24] Tuncali, T. (2010): Kapıdağ Yarımadası (Balıkesir) üzerinden süzülerek göç eden kuşların ilkbahar göçünün araştırılması (Research on the soaring bird migration in spring over Kapidag Peninsula (Balikesir)). - Uludağ Üniversitesi, Fen Bilimleri Enstitüsü Yüksek Lisans Tezi (Masters Thesis), Bursa (unpublished, in Turkish).

[25] Üner, Ö., Boyla, K. A., Bacak, E., Birel, E., Çelikoba, I., Dalyan, C., Tabur, E., Yardim, Ü. (2010): Spring migration of soaring birds over the Bosphorus Turkey in 2006. Sandgrouse 32: 20-33.

[26] Vittery, A., Squire, J. F. (1972): Bird Report No. 2 (1968-1969). - Ornithological Society of Turkey, Sandy, Bedfordshire. 